\title{
PERANCANGAN SISTEM MODEL PENENTU PEMBERIAN PINJAMAN KOPERASI KARYAWAN PERMATA BANK MENGGUNAKAN SVM
}

\author{
Purwanti $^{1}$, Tuti Handayani ${ }^{2}$ \\ Program Studi Teknik Informatika, Universitas Indraprasta PGRI ${ }^{1,2}$ \\ Email:Pwanty7@gmail.com ${ }^{1}$ \\ Email: mail_tuti_hani@yahoo.com ${ }^{2}$
}

\begin{abstract}
Abstrak
Saat ini pinjaman merupakan salah satu sumber keuntungan bisnis yang dengan resiko tinggi. Banyak metode klasifikasi telah diusulkan dalam literatur untuk mengatasi masalah ini. Tapi kebanyakan tidak diterima oleh para ahli karena berbagai alasan. Kebutuhan untuk mengetahui dan membedakan antara anggota baik dan yang buruk perlu dibangun sehingga pihak yang berkepentingan dapat mengambil salah satu tindakan pencegahan terjadinya masalah pinjaman macet. Dalam penelitian ini dilakukan model support vector macine (SVM) terhadap data Anggota pinjaman koperasi baik yang bermasalah dalam pembayaran angsurannya maupun tidak. Dari hasil pengujian dengan mengukur kinerja algoritma tersebut menggunakan metode pengujian confusio matrix dan kurva ROC, diketahui bahwa algoritma Support vector macine memiliki nilai accuracy tinggi. Sehingga dapat diterapkan untuk permasalahan penentuan kelayakan pinjaman koperasi.
\end{abstract}

Kata kunci: Koperasi , SVM, Confusion Matrix, Kurva ROC.

\begin{abstract}
Currently, a loan is one of profitable business with a high risk. Many classification methods have been suggested in the literature to overcome this problem. But most are not accepted by experts for various reasons. Therefore, it is necessary to identify and distinguish between good and bad members so that the interested parties can take anactionto prevent nonperforming loans. This study usesSupport Vector Machine (SVM)Model to process the data on cooperative loan members either those in trouble with the installment payment or not. The result of the test by measuring the performance of the algorithm using the test method confusio matrix and ROC curves shows that the Support Vector Machine algorithm has high accuracy. In conclusion, it can be applied to determine the feasibility of a cooperative loan.
\end{abstract}

Keywords : Cooperative, SVM, Confusion Matrix, ROC curve.

\section{Pendahuluan}

Penelitian mengenai analisis kelayakan pemberian pinjaman anggota koperasi dengan metode klasifikasi data mining telah banyak dilakukan, namun belum diketahui metode klasifikasi data mining yang paling akurat dalam melakukan analisis kelayakan pinjaman anggota tersebut. Dari penelitian-penelitian yang pernah dilakukan, evaluasi resiko pinjaman merupakan masalah yang menarik dalam analisa keuangan. Beberapa teknik seperti neural network, svm, dan lainnya telah digunakan untuk analisa kelayakan pinjaman anggota koperasi.

Penelitian ini bertujuan untuk menganalisa dan menerapkan algoritma SVM untuk sistem untuk penilaian kelayakan anggota yang akan menerima pinjaman dari koperasi, dan diharapkan mampu mengurangi dari kredit macet. Keutamaan dalam penelitian ini diharapkan dapat membantu Koperasi dalam Menentukan penilaian kelayakan dalam pinjaman anggota koperasi.

\section{Tinjauan Pustaka}

\section{Koperasi}

Pengertian koperasi secara sederhana berawal dari kata "co" yang berarti bersama dan 
"operation" (Koperasi operasi) artinya bekerja. Jadi pengertian koperasi adalah kerja sama. Sedangkan pengertian umum koperasi adalah : suatu kumpulan orang-orang yang mempunyai tujuan sama, diikat dalam suatu organisasi yang berasaskan kekeluargaan dengan maksud mensejahterakan anggota.

Koperasi adalah badan usaha yang beranggotakan orang seorang atau badan hukum koperasi dengan melandaskan kegiatannya berdasarkan prinsip koperasi sekaligus sebagai gerakan ekonomi rakyat yang berdasarkan atas asas kekeluargaan (Arman, 2009: 15).

\section{KDD (Knowledge Discovery in Database)}

Menurut (Maimon \& Rokach 2010) Knowledge Discovery in data yang besar. KDD adalah proses terorganisir identifikasi yang valid, pola baru, berguna,dan dapat dimengerti dari kumpulan data besar dan kompleks. Data Mining (DM) adalah inti dari proses KDD, yang melibatkan menyimpulkan algoritma yang mengeksplorasi data, mengembangkan model danmenemukan pola-pola sebelumnya yang tidak diketahui. Model ini digunakan untuk memahami fenomena dari analisis, data dan prediksi.

\section{Data Mining}

Data mining adalah gabungan ilmu statistik, kecerdasan buatan, dan penelitian database (Gorunescu, 2011:1). Menurut Witten \& Frank (2011:20), d ata mining adalah pemecahan masalah dengan menganalisis data sudah ada dalam database.

Menurut Han (Han, 2012, 6) menjelaskan bahwa atau dengan istilah menggali pengetahuan dari jumlah data yang banyak. Selain itu, Han (Han , 2012, 36)menjelaskan lagi bahwa data mining adalah proses menemukan pola yang menarik, dan pengetahuan dari data yang berjumlah besar.

\section{Populasi dan Sampel}

Populasi adalah wilayah generalisasi yang terdiri atas: obyek/subyek yang mempunyai kualitas dan karakteristik tertentu yang ditetapkan oleh peneliti untuk dipelajari dan kemudian ditarik kesimpulannya (Sugiyono, 2011:80).

\section{Konsep Support vector machin}

Support Vector Machine (SVM) adalah metode supervised dimana dalam tahap training kita ingin menemukan parameter dual, a dan bias b. Setelah ditemukan kedua parameter yang optimal melalui optimasi program kuadrat(quadratic programming). Jika ukurannya problem cukup besar, solver program akuadrad biasanya lambat (Santoso, 2007:103). SVM adalah suatu teknik yang baru (1995) untuk melakukan prediksi, baik dalam kasus klasifikasi maupun regresi yang sangat popular pada saat ini. SVM berada dalam satu kelas dengan ANN dalam hal fungsi dan kondisi permasalahan yang biasa diselesaikan. Keduanya masuk dalam kelas supervised learning. Baik para ilmuwan ataupun praktisi telah banyak menerapkan teknik ini dalam menyelesaikan masalah-masalah nyata dalam kehidupan sehari-hari. Baik dalam masalah gene exception analysis, financial,cuaca hingga pada bidang kedokteran. Terbukti dalam banyak implementasi, SVM member hasil yang lebih baik dari ANN, terutama dalam solusi yang dicapai. ANN menemukan solusi berupa local optimal sedangkan SVM menemukan solusi yang global optimal (Budi Santoso,2007:103)

\section{Metodologi Penelitian}

\section{Jenis Penelitian}

Penelitian eksperimen pada prinsipnya dapat didefinisikan sebagai metode sistematis guna membangun hubungan yang mengandung fenomena sebab akibat (causal-effect relationship) (Sukardi 2011:179). Selanjutnya, metode eksperimen adalah metode penelitian yang digunakan utuk mencari pengaruh perlakuan tertentu terhadap yang lain dalam kondisi yang terkendalikan (Sugiyono 2011:72). Berdasarkan definisi dari beberapa ahli tersebut, dapat dipahami bahwa penelitian eksperimen adalah penelitian yang dilakukan untuk mengetahui pengaruh pemberian suatu treatment atau perlakuan terhadap subjek penelitian. 
Jadi penelitian eksperimen dalam pendidikan adalah kegiatan penelitian yang bertujuan untuk menilai pengaruh suatu perlakuan/tindakan/treatment pendidikan terhadap tingkah laku siswa atau menguji hipotesis tentang ada-tidaknya pengaruh tindakan itu jika dibandingkan dengan tindakan lain.

Penelitian ini adalah penelitian eksperimen. Penelitian ini bertujuan untuk mengukur akurasi algoritma SVM. Data yang digunakan dalam penelitian dari data kosioner dimana setiap anggota koperasi yang ingin diperoleh pinjaman harus mengisi kuisioner. Dari sistem tersebut diambil beberapa variabel atau atribut yang akan di analisa menggunakan komparasi data mining dan akan di tarik kesimpulan dari hasil analisa.

\section{Kerangka Pendekatan Penelitian}

Penelitian ini menggunakan data eksperimen, yaitu data anggota dan data kuisioner yang berkaitan yaitu data pinjaman. Kemudian ditentukan atribut yang akan digunakan dalam data mining.

Proses identifikasi masalah dilakukan dengan melihat, mengamati dan memahami proses bisnis Koperasi pada sistem pembiayaan yang dilakukan, secara langsung maupun melalui pemahaman terhadap data yang diperoleh dari sistem pembiayaan, untuk menentukan objek penelitian data mining, mengetahui hubungan antara data yang satu dengan data lainnya dan untuk mengetahui atribut yang digunakan. Objek penelitian ditentukan dengan menggunakan teknik data mining untuk mendapatkan prediksi algoritma yang tepat terhadap calon anggota koperasi yang akan menerima pinjaman.

\section{Model dan Variabel}

Persiapan data dilakukan berdasarkan penemuan masalah yang terdapat pada sistem pembiayaan. Permasalahan yang ditemukan dalam penelitian ini yaitu adanya kenaikan jumlah pinjaman tidak layak. Atribut yang digunakan adalah sebagai berikut :

Tabel 1. Atribut dan nilai kategori

\begin{tabular}{|c|c|c|}
\hline NO & Atribut & Nilai \\
\hline 1 & Jenis kelamin & $\begin{array}{l}\text { Laki-laki } \\
\text { Perempuan }\end{array}$ \\
\hline 2 & Status perkawinan & $\begin{array}{l}\text { Menikah } \\
\text { Belum menikah } \\
\text { Janda/duda }\end{array}$ \\
\hline 3 & Jumlah tanggungan & $\begin{array}{l}1 \text { orang } \\
2-3 \text { orang } \\
>3 \text { orang } \\
\text { Tidak ada }\end{array}$ \\
\hline 4 & Pendidikan terakhir & $\begin{array}{l}>\text { S1 } \\
\text { S1 } \\
\text { Diploman } \\
\text { SLTA } \\
\text { SLTP } \\
\text { SD } \\
\text { Tidak sekolah } \\
\end{array}$ \\
\hline 5 & Usia & $\begin{array}{l}<21 \text { tahun atau }>60 \text { tahun } \\
21-55 \text { tahun } \\
55-60 \text { tahun }\end{array}$ \\
\hline 6 & Status tempat tinggal & $\begin{array}{l}\text { Rumah sendiri } \\
\text { Rumah dinas } \\
\text { Rumah kontrak } \\
\end{array}$ \\
\hline 7 & Masa anggota & $\begin{array}{l}3-5 \text { tahun } \\
1-3 \text { tahun } \\
<1 \text { tahun }\end{array}$ \\
\hline 8 & Jenis pekerjaan & $\begin{array}{l}\text { PNS } \\
\text { POLRI } \\
\text { Jaksa } \\
\text { Karyawan } \\
\text { Wiraswasta kecil } \\
\text { Wiraswasta menengah } \\
\text { Wiraswasta besar } \\
\text { Konsultasi }\end{array}$ \\
\hline
\end{tabular}




\begin{tabular}{c|l|l}
\hline & & Dokter \\
& & Guru \\
Dosen \\
Pengacara \\
Pensiunan
\end{tabular}

\section{Populasi dan Sampel}

Data yang didapat dari penelitian ini sebanyak 2000 record baik yang macet ataupun lancar, yang terdiri dari 15 atribut. Untuk mendapatkan data yang berkualitas, beberapa teknik preprocessing.

Setelah dilakukan preprocessing data yang didapat sebanyak 2000 record, setelah direduksi dengan menghilangkan duplikasi menjadi 500 record. Untuk data training yang diambil sebanyak 400 data. Untuk data testing atau sampel diambil sebanyak 100 data, dan untuk penerapan diambil sebanyak 20 data. Untuk pemisahan data tersebut menggunakan tehnik Systematic Random Sampling (Eriyanto, 2007).

\section{Metode Pengukuran Data \\ Data Primer}

Data primer diperoleh melalui eksperimen. Dari penelitian eksperimen tersebut didapatkan sebuah data kuisioner dimana setiap anggota koperasi yang ingin diperoleh pinjaman harus mengisi form kuisioner. eksperimen dilakukan dengan mengamati, mempelajari data kosioner. Melalui pengamatan data tersebut ditentukan atribut yang berhubungan dengan permasalahan dari anggota koperasi yang mengalami pinjaman tidak layak.

\section{Data Sekunder}

Data sekunder di peroleh melalui Studi literatur. Studi literatur merupakan pengumpulan data informasi yang dilakukan dengan mempelajari data mining, metode, tools yang akan digunakan, melalui literatur-literatur seperti jurnal, artikel, buku, laman web dan dokumen-dokumen teks yang berhubungan dengan objek penelitian ini.

\section{Analisis Data \\ Domain Understanding dan KDD Goals}

Tahap ini dilakukan pencarian masalah dalam penentuan kelayakan pinjaman, kemudian merumuskan masalah dan menganalisa kebutuhan untuk memecahkan 
masalah tersebut.

\section{Selection and Addition}

Mengumpulkan data pada tahap ini dilakukan dengan cara eksperimen. Data yang didapat, kemudian dianalisa untuk menentukan atribut dan record apa saja yang diperlukan.

\section{Preprocessing Data Cleaning}

Pada tahap ini di lakukan pembersihan data. Data yang didapat dari penelitian ini sebanyak 2000 data baik yang macet ataupun lancar, yang terdiri dari 15 atribut. Setelah dihilangkan duplikasi dan null value menjadi 500 record.

\section{Evaluation and Interpretation}

Pada tahap ini adalah tahap dilakukan pengujian menggunakan data training berjumlah 400 dan data testing berjumlah 100 data dengan melihat hasil akurasi pada proses klasifikasi menggunakan metode Support vector macine, Genetic Algorithms, dan Neural Network. Serta evaluasi dengan menggunakan metode confusion matrix, dan kurva ROC.

\section{Discovered Knowledge}

Setelah pembentukan model, dilakukan analisa, danpengukuran, selanjutnya pada tahap ini diterapkan model yang paling akurat untuk penentuan kelayakan pemberian pinjaman koperasi pada koperasi dengan menggunakan data baru pada sebuah aplikasi menggunakan Rapid Miner.

\section{Bagan Alir Penelitian}

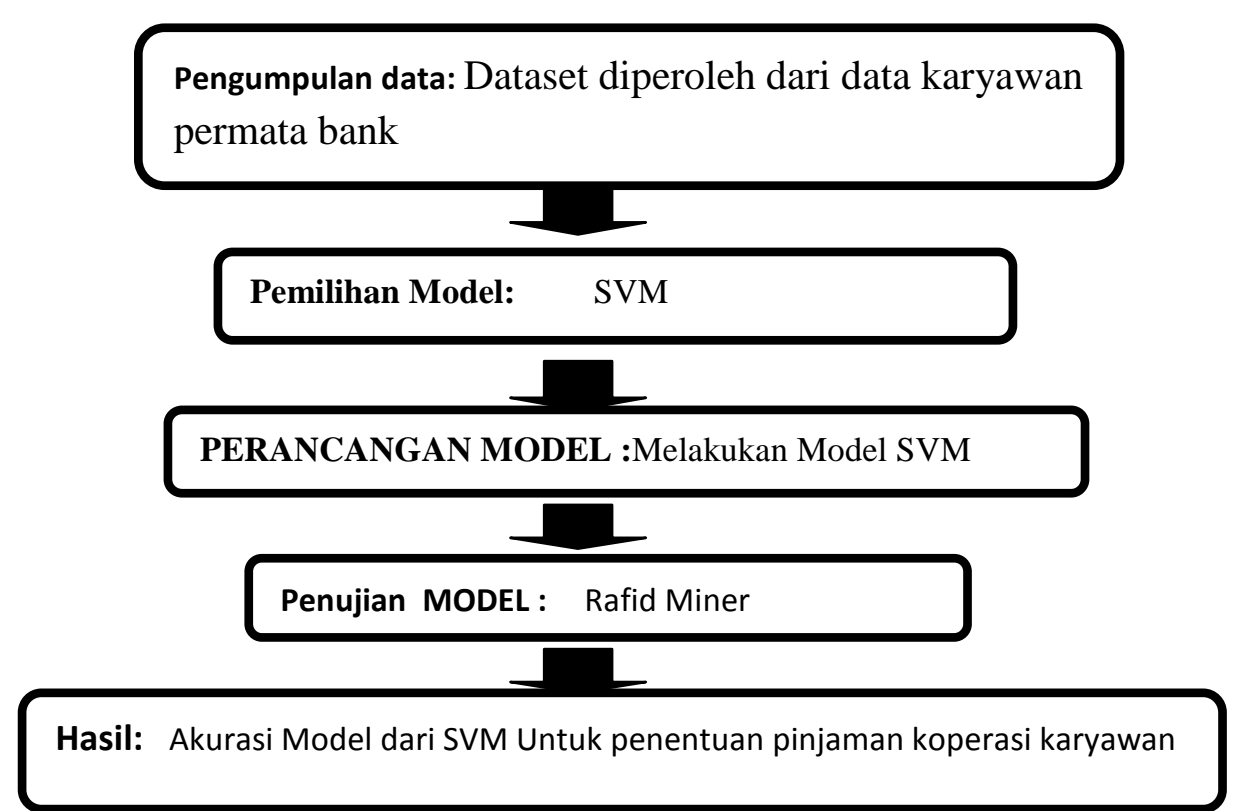

\section{Gambar 1. Bagan Alir Penelitian}

\section{Hasil dan Pembahasan}

\section{Support Vector Machine}

Data training adalah untuk menentukan apakah seorang anggota koperasi layak atau tidak layak dalam pemberian pinjaman. Berikut akan dibahas prediksi apakah anggota koperasi bermasalah atau tidak, menggunakan metode klasifikasi support vector machine sehingga didapat Karnel Model dari rafid miner dengan bobot dari masing masing atribut. 
Tabel 2. Nilai Bobot Support Vector Machine

\begin{tabular}{|c|c|c|}
\hline NO & Atribute & Weight \\
\hline 1 & Jenis Kelamin = Perempuan & -0.00702 \\
\hline 2 & Jenis Kelamin $=$ Laki-laki & 0.007309 \\
\hline 3 & Status perkawinan $=$ Janda/duda & -0.04731 \\
\hline 4 & Status perkawinan $=$ Menikah & 0.06993 \\
\hline 5 & Status perkawinan $=$ Belum menikah & -0.05885 \\
\hline 6 & Jumlah tanggungan $=2-3$ orang & 0.030238 \\
\hline 7 & Jumlah tanggungan $=1$ orang & 0.060073 \\
\hline 8 & Jumlah tanggungan $=$ Tidak ada & -0.08156 \\
\hline 9 & Jumlah tanggungan $=>3$ orang & 0.004764 \\
\hline 10 & Pendidikan terakhir $=$ Diploman & -0.00925 \\
\hline 11 & Pendidikan terakhir $=\mathrm{S} 1$ & -0.01181 \\
\hline 12 & Pendidikan terakhir $=$ SLTA & 0.022902 \\
\hline 13 & Pendidikan terakhir $=$ tidak sekolah & -0.10055 \\
\hline 14 & Pendidikan terakhir $=>\mathrm{S} 1$ & 0.034253 \\
\hline 15 & Pendidikan terakhir $=$ SLTP & 0.047266 \\
\hline 16 & Pendidikan terakhir $=\mathrm{SD}$ & 0.012674 \\
\hline 17 & Usia $=21$ tahun atau $>60$ tahun & 0.063118 \\
\hline 18 & Usia $=21-55$ tahun & -0.02137 \\
\hline 19 & Usia $=55-60$ tahun & -0.04283 \\
\hline 20 & Status tempat tinggal $=$ Rumah sendiri & 0.01248 \\
\hline 21 & Status tempat tinggal = Rumah kontrak & 0.03542 \\
\hline 22 & Status tempat tinggal $=$ Rumah dinas & -0.05872 \\
\hline 23 & Masa anggota $=<1$ tahun & -0.02106 \\
\hline 24 & Masa anggota $=1-3$ tahun & 0.027688 \\
\hline 25 & Masa anggota $=>3$ tahun & -0.00828 \\
\hline 26 & Jenis pekerjaan $=$ Konsultasi & 0.01098 \\
\hline 27 & Jenis pekerjaan $=$ Wiraswasta besar & 0.031926 \\
\hline 28 & Jenis pekerjaan = Karyawan & -0.02709 \\
\hline 29 & Jenis pekerjaan $=$ Guru & -0.03758 \\
\hline 30 & Jenis pekerjaan = Pengacara & -0.01391 \\
\hline 31 & Jenis pekerjaan $=$ Jaksa & 0.041771 \\
\hline 32 & Jenis pekerjaan $=$ Wiraswasta kecil & 0.026606 \\
\hline 33 & Jenis pekerjaan $=$ POLRI & 0.036362 \\
\hline 34 & Jenis pekerjaan $=$ Dokter & 0.039201 \\
\hline 35 & Jenis pekerjaan = Wiraswasta menengah & -0.05828 \\
\hline 36 & Jenis pekerjaan = Dosen & 0.030386 \\
\hline 37 & Jenis pekerjaan $=$ Pensiunan & -0.07623 \\
\hline 38 & Jenis pekerjaan $=$ PNS & 0.012583 \\
\hline 39 & Masa kerja $=2-5$ tahun & 0.026698 \\
\hline 40 & Masa kerja $=>5$ tahun & -0.10096 \\
\hline 41 & Masa kerja $=<2$ tahun & 0.062297 \\
\hline
\end{tabular}




\begin{tabular}{r|l|r}
\hline 42 & Besar pinjaman = 10.000.001-25.000.000 & -0.12928 \\
\hline 43 & Besar pinjaman = 1.000.001-5.000.000 & -0.24734 \\
\hline 44 & Besar pinjaman = 5.000.000-10.000.000 & -0.27074 \\
\hline 45 & Besar pinjaman = 50.000.001-100.000.000 & 0.268363 \\
\hline 46 & Besar pinjaman = 500.000-1.000.000 & -0.24119 \\
\hline 47 & Besar pinjaman = 25.000.001-50.000.000 & 0.049759 \\
\hline 48 & Besar pinjaman = 100.000.001-500.000.000 & 0.510117 \\
\hline 49 & Besar pinjaman = 500.000.001-1M & 0.497689 \\
\hline 50 & Type pinjaman = Tempo & -0.06638 \\
\hline 51 & Type pinjaman = Angsuran & 0.04957 \\
\hline 52 & Jangka pinjaman => 36 Bulan ( Pajang) & -0.22013 \\
\hline 53 & Jangka pinjaman =1-12 Bulan (Pendek) & 0.312707 \\
\hline 54 & Jangka pinjaman =13-36 Bulan ( Menengah) & -0.06433 \\
\hline 55 & gaji pokok = 0-1 juta & 0.247425 \\
\hline 56 & gaji pokok = 2-3 juta & -0.00893 \\
\hline 57 & gaji pokok = 5-6 juta & -0.16657 \\
\hline 58 & gaji pokok = 3-4 juta & -0.0019 \\
\hline 59 & gaji pokok = 4-5 juta & -0.06816 \\
\hline 60 & Beban lain = Mobil & -0.03947 \\
\hline & &
\end{tabular}

\section{Pengujian Model}

Model yang telah dibentuk diuji tingkat akurasinya dengan memasukan data uji yang berasal dari data training. Karena data yang didapat dalam penelitian ini setelah proses preprocessing hanya 400 data maka digunakan metode cross validation untuk menguji tingkat akurasi. Untuk nilai akurasi model untuk metode SVM sebesar 88.00\%.

\section{Confusion Matrix algoritma SVM}

Tabel 3 adalah perhitungan akurasi data training menggunakan algoritma SVM Diketahui dari 400 data training, dengan menggunakan metode algoritma SVM didapat klafikasi 288 data prediksi layak sesuai memang layak, 32 data prediksi Layak ternyata memang tidak layak, didapat klasifikasi 16 data prediksi tidak layak ternyata malah layak, dan 64 data prediksi tidak layak memang sesuai dengan tidak layak.

Tabel 3. Confussion Matrix Data Training untuk Algoritma SVM

\begin{tabular}{clccc}
\hline No & \multicolumn{1}{c}{ Name } & True layak & True tidak layak & Class precision \\
\hline 1. & Pred.Layak & 288 & 32 & $90.00 \%$ \\
2. & Pred.Tidak Layak & 16 & 64 & $80.00 \%$ \\
3. & Class recall & $94.74 \%$ & $66.67 \%$ & \\
\hline
\end{tabular}

Perhitungan nilai akurasi dari confusion matrix tersebut adalah sebagai berikut:

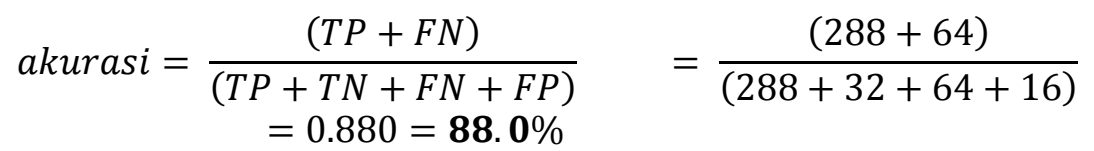

$$
\begin{aligned}
& \text { precision }=\frac{F N}{(F N+F P)} \\
& =\frac{64}{(64+16)} \\
& =0.80=\mathbf{8 0 . 0 0} \%
\end{aligned}
$$




$$
\begin{aligned}
\text { recall } & =\frac{F N}{(F N+T N)} \\
& =\frac{64}{(64+32)} \\
& =0.6667 \\
& =66,67 \%
\end{aligned}
$$

Performance Vector pada rafidminer

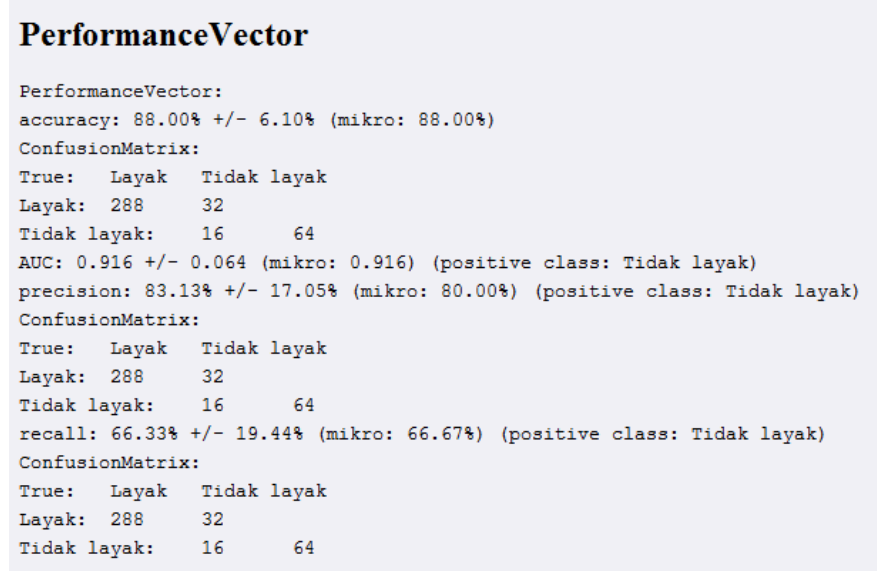

\section{Gambar 2. Text View Model Confusion Matrix untuk algoritma SVM}

\section{Confusion Matrix}

Dari tabel confusion matrix, selanjutnya dilakukan perhitungan nilai accuracy, precision, dan recall. dapat dilihat pada Tabel 4.

\begin{tabular}{clc}
\multicolumn{2}{c}{ Tabel } & 4. \\
Nilai Accuracy, & Precision, dan Recall \\
\hline No & Algoritma SVM & Nilai \\
\hline 1 & Accuracy & $88.00 \%$ \\
2 & Precision & $80.00 \%$ \\
3 & Recall & $66.67 \%$ \\
\hline
\end{tabular}

\section{Kurva ROC}

Hasil perhitungan divisualisasikan dengan kurva ROC, bisa dilihat pada Gambar 3 yang merupakan kurva ROC untuk algoritma SVM.

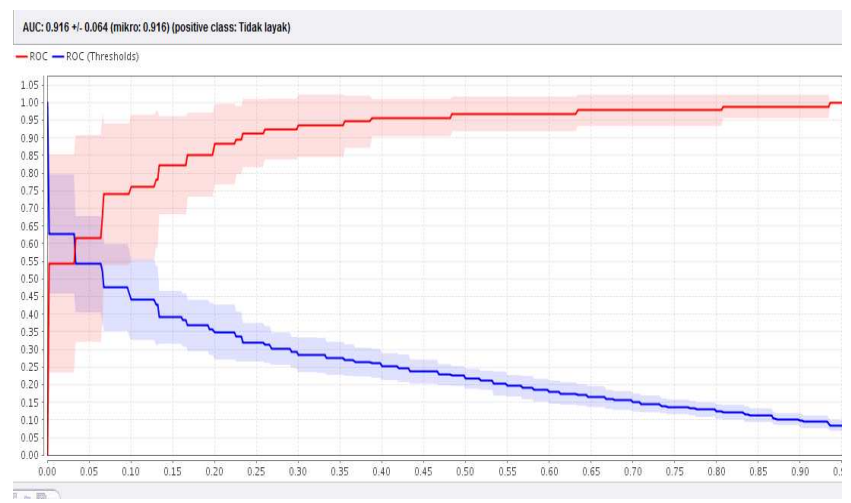

Gambar 3. Kurva ROC dengan Algoritma SVM 


\section{Analisis Hasil}

Model yang dihasilkan dengan metode SVM diuji menggunakan metode Cross Validation, terlihat perbandingan nilai accuracy, precision, sensitivity, dan recall pada Tabel 5.

Tabel 5. Nilai Accuracy dan AUC

\begin{tabular}{rlc}
\hline No. & Algoritma SVM & Nilai \\
\hline 1 & Accuracy & $88.00 \%$ \\
2 & AUC & 0.916 \\
\hline
\end{tabular}

Tabel 5 membandingkan accuracy dan AUC dari tiap metode. Terlihat bahwa nilai accuracy menunjukan nilai yang sesuai. Untuk klasifikasi data mining, nilai AUC dapat dibagi menjadi beberapa kelompok

a. $0.90-1.00=$ klasifikasi sangat baik

b. $0.80-0.90=$ klasifikasi baik

c. $0.70-0.80=$ klasifikasi cukup

d. $0.60-0.70=$ klasifikasi buruk

e. $0.50-0.60=$ klasifikasi salah

Berdasarkan pengelompokkan di atas dan Tabel 5 maka dapat disimpukan bahwa metode SVM termasuk klasifikasi cukup karena memiliki nilai AUC antara 0.90-1.00.

\section{Hasil Algoritma Terpilih}

Berdasarkan hasil perbandingan akurasi pada tabel 5 algoritma terpilih sebagai algoritma terbaik dalam klasifikasi penentuan pinjaman karyawan koperasi yaitu algoritma $S V M$ yang memiliki tingkat akurasi tertinggi dengan persentase $88,00 \%$ dilakukan penerapan pada data baru (tabel 5).

Hasil klasifikasi dari algoritma SVM diterapkan kedalam pembuatan aplikasi untuk klasifikasi penentu pinjaman koperasi karyawan dengan menggunakan MATLAB seperti pada gambar 4.

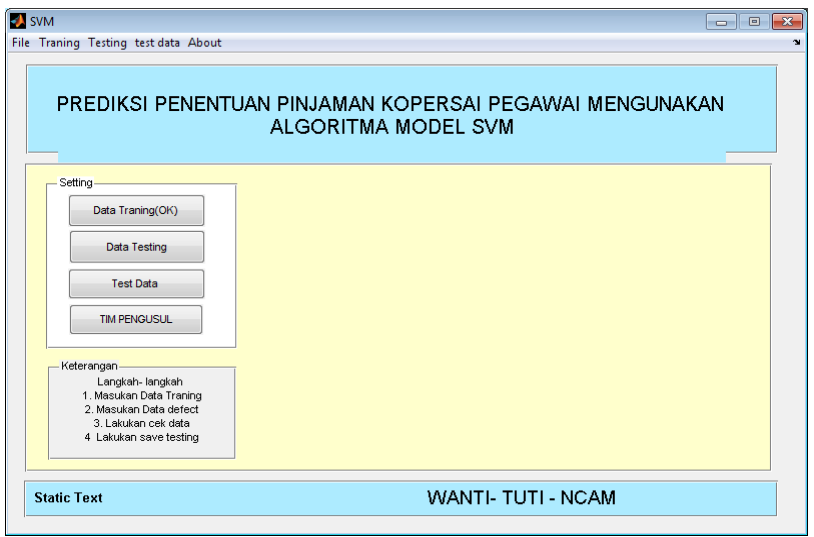

Gambar 4. Aplikasi untuk Klasifikasi Penentuan Pinjaman Koperasi Karyawan Form Data Training 


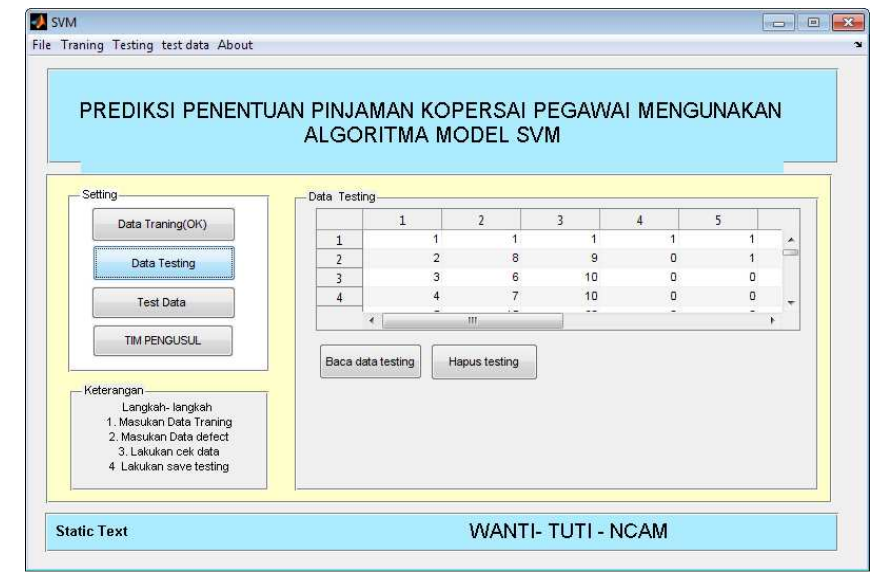

Gambar 5. Aplikasi untuk Klasifikasi Penentu Pinjaman Koperasi Karyawan Form Data Testing

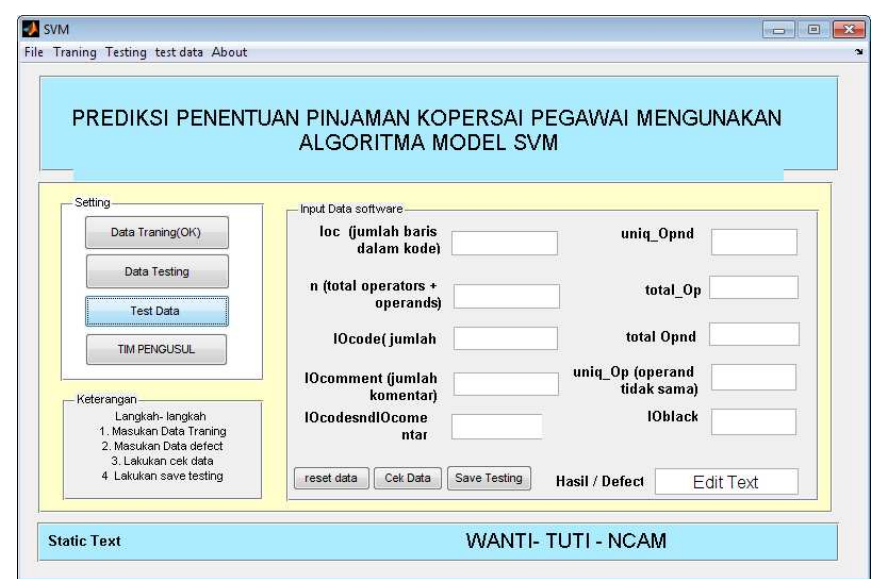

Gambar 6. Aplikasi untuk Klasifikasi Penentu Pinjaman Koperasi Karyawan From Test Data

Pada aplikasi untuk klasifikasi penentu pinjaman koperasi karyawan pada gambar di atas dihasilkan klasifikasi layak dan tidak layak input data anggota koperasi pada program tersebut sesuai dengan atribut yang dibutuhkan, kemudian klik tombol cek data, maka secara otomatis tampil hasil klasifikasi penentu pinjaman koperasi karyawan yang layak atau tidak layak

\section{Simpulan}

Dalam penelitian ini dilakukan pembuatan model baru yang diusulkan dengan metode SVM yang dilakukan pada koperasi karyawan permata bank. Untuk menghasilkan nilai yang paling akurat, maka digunakan cross validation pada tahap pengujian untuk. Eksperimen pada model dievaluasi dan divalidasi dengan confusion Matrix dan AUC(Area Under Curve) dengan ROC (Receiver Operating Characteristic).

Berdasarkan hasil evaluasi dan validasi dapat dikesimpulan bahwa, algoritma SVM memiliki akurasi dan performa sangat baik secara rata-rata untuk semua dataset yaitu sebesar $88,00 \%$ dan nilai AUC(Area Under Curve) sebesar 0.916.

\section{Saran}

SVM lebih akurasi dan performa sangat baik. Meskipun demikian ada beberapa metode yang lain memiliki keunggulan dan mendominasi pada nilai hasil yang tergatung pada dataset. Oleh karena itu diperlukan penelitian lanjut untuk menentukan model yang paling mendominasi dan unggul terhadap semua data set. 


\section{Daftar Pustaka}

Arman, A. (2009). Pokok-pokok Pikiran dan Manajemen Koperasi. Jakarta: Balai Pustaka.

Santosa, B. (2007). Aplikasi Metode Cross Entropy Untuk Support Vector Machines Data. Yogyakarta: Graha Ilmu.

Eriyanto. (2007). Teknik Sampling Analisis Opini Publik. Yogyakarta

Gorunescu. (2011). Data Mining: Concepts, Models, and Techniques. Verlag Berlin Heidelberg: Springer

Han, J, Kamber, M, \& Pei, J. (2012). Data Mining: Concept and Techniques, Third Edition. Waltham: Morgan Kaufmann Publishers.

Maimon, Oded \& Rokach, Lior. 2010. Data Mining and Knowledge Discovey Handbook. New York: Springer

Moedjiono. (2012). Pedoman Penelitian, Penyusunan dan Penilaian Tesis (V.5). Jakarta: Universitas Budi Luhur.

Sugiyono. (2011). Metode Penelitian Kuantitatif, Kualitatif, dan $R$ \& D. Bandung: AFABETA.

Sukardi. (2011). Metodologi Penelitian Pendidikan Kompetensi dan Praktiknya. Jakarta: PT Bumi Aksara.

Witten, I. H., Frank, E., \& Hall, M. A, 2011. Data Mining: Practical Machine Learning and Tools. Morgan Kaufmann Publisher. Burlington. 